\title{
Characteristic Analysis of the Organic Substance and Nutrient Removal and the Green House Gas Emission in the Soil Treatment Systems with Aquatic Plants
}

\author{
RYUHEI INAMORI ${ }^{1}$, KAI-QIN XU², PING GUI², YOSHITAKA EBIE², YUHEI INAMORI ${ }^{2}$, \\ and MASATOSHI MATUMURA ${ }^{1}$ \\ ${ }^{1}$ University of Tsukuba/1-1-1 Tennodai, Tsukuba 305-8577, Japan \\ ${ }^{2}$ National Institute for Environmental Studies/16-2 Onogawa, Tsukuba 305-8506, Japan
}

\begin{abstract}
In this study, characteristic analysis of the organic substance and nutrient removal and the green house gas emission in the soil treatment systems with aquatic plants was evaluated. From this study various outcomes were obtained: Soil treatment systems using aquatic plants have removal capabilities of $90 \%$ (BOD removal rate $3.7 \mathrm{~g} \cdot \mathrm{m}^{-2} \cdot \mathrm{d}^{-1}$ ) of organic substances including BOD and COD; similarly, the removal capabilities of nutrients including nitrogen and phosphorus were $90 \%$ (Nitrogen removal rate 0.9

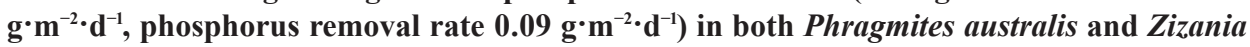
latifolia units with a low level of pollution loads; the removal capabilities in both $P$. australis and $Z$. latifolia units with a high level of pollution load dropped to $50 \%, P$. australis units showed particularly low results in the winter; and with regard to greenhouse gases, $P$. australis units showed low $\mathrm{CH}_{4}$ generation while $Z$. latifolia showed a high value. These results revealed the characteristics of one method of ecoengineering. The overview results of this study can be summarized as follows: 1$)$ Although both $P$. australis and $Z$. latifolia showed BOD removal rates of $90 \%$ or more, the load of BOD $200 \mathrm{mg} \cdot l^{-1}$ was too high for $P$. australis in the beginning of vegetation. 2) Both $P$. australis and $Z$. latifolia showed relatively stable nitrogen removal capability from summer to autumn, but its perfermences slightly decreased in winter due to the low temperature. 3) The generation rate of $\mathrm{CH}_{4}$ in $\mathrm{Z}$. latifolia units was higher in all the loading levels of BOD 50, 100, and $200 \mathrm{mg} \cdot l^{-1}$, than in those in $P$. australis units. 4) Soil treatment systems using aquatic plants keep high purifying capabilities in low pollution loads such as BOD $50 \mathrm{mg} \cdot l^{-1}$ when water temperature is low.
\end{abstract}

Key words: Aquatic plant, Soil purification system, Nutrient removal, Green house gas, Constructed wetland

\section{INTRODUCTION}

Recently, two topics have attracted attention as important environmental issues in Japan and other countries: eutrophication, such as red tides in inland seas and inner bays, and water blooms in lakes; and global warming caused by $\mathrm{CO}_{2}, \mathrm{CH}_{4}$ (methane) and
$\mathrm{N}_{2} \mathrm{O}$ (nitrous oxide), which were added to the list of green house gases at COP3 (the Third Session of the Conference of the Parties), when the Kyoto Protocol was adopted ${ }^{11}$. In order to prevent these problems, it is of great importance to take measures in various areas, particularly, actions to reduce the environmental loads caused by household 
effluents are essential ${ }^{2,3)}$. These actions can be roughly divided into two categories: bioengineering and ecoengineering as approaches to water treatment engineering ${ }^{4}$. Of these two approaches, the utilization of ecoengineering is crucial.

Ecoengineering is a method to introduce engineering technology into natural ecosystems to improve the efficiency of purifying actions to remove pollutants for environmental remediation. This technology is starting to be utilized to make biotopes in which wildlife can live, and to purify water in water areas such as rivers, lakes, and tidal flats. In other words, ecoengineering is a technology to control the organic interactions of variety of wildlife and their living environments from an engineering perspective. The wildlife here includes low-level algae and bacteria, their predators such as protozoa and micro metazoa, and fish and birds, comprising food chains and food webs, which are the bases of ecosystems $\mathrm{s}^{5}$. The living environments include water areas, continental areas, and wetlands. Through the use of this technology, it is expected that the functions of these objects of control, such as those for industry, degradation, absorption, and purification, can be made more efficient, and environmental conservation and remediation can be achieved. Ecoengineering methods have the following characteristics:

1) Not only organic materials, but also nitrogen and phosphorus can be cleaned up $^{6,7)}$.

2) Since the building cost is low, it is possible to construct large scale facilities.

3) The maintenance is easy and inexpensive.

4) Efficient use of aquatic plants, vegetables, and flowers makes it possible to recycle resources.

5) Using accumulated mud and plants as compost and feed enables resources recycling.

6) Not only biotopes can be created, but also the landscape can be enhanced for use as recreation areas such as water parks.

7) People can participate voluntarily to help improve the environment.

8) It can provide sites for environmental education, and enlighten people about improvement of the environment.
Thus, the application of ecoengineering methods is important in creating resourcerecycling type local ecosystems and establishing effective purifying systems. A purifying system that utilizes sediment with vegetation is the focus of this experiment. This system has functions such as removal of nitrogen and phosphorus by absorption of plants, degradation and removal of organic substances and nutrient due to the filtration by biofilms attached to the rootstalks of plants, filtration of SS by aquatic plants, purifying actions by nitrifiers and denitrifiers in sediment that accumulate during purification, and purifying actions by food chains in rootstalks and plant bodies in water $^{8)}$. In addition, filtration by emergent plants and hydroponic plants has revealed the absorption of oxygen from stems and leaves in aerial parts, and promoting action for degradation of organic substances, and nitrification of ammonia-nitrogen.

In the bottom sediment, free oxygen $\left(\mathrm{O}_{2}\right)$ absorbed from leaves transfers to the rhizosphere via rootstalks. Soil around the rhizosphere turns aerobic, and ammonia is nitrified by nitrifiers. Soil farther away from the rhizosphere turns to a facultative anaerobic environment where nitrogen is removed by producing $\mathrm{N}_{2}$ gas due to denitrification by denitrifiers. These reactions, nitrification and denitrification, lead to efficient water purification. These processes may generate nitrous oxide $\left(\mathrm{N}_{2} \mathrm{O}\right)$, which is a greenhouse gas, under certain conditions ${ }^{9,10)}$. In the denitrification process, denitrifiers require $\mathrm{BOD}(\mathrm{C})$ as an energy source, $\mathrm{NO}_{2}-\mathrm{N}$ and $\mathrm{NO}_{3}-\mathrm{N}$ as bound oxygen for a source of respiration, and when $\mathrm{C} / \mathrm{N}$ balance is decreased to 3 or less, $\mathrm{N}_{2} \mathrm{O}$ is generated. Accordingly, adjusting to the optimum operation conditions is very important. In addition, since when the condition turns anaerobic, the number of methanogenic bacteria increases and methane gas is generated, the transformation of $\mathrm{CH}_{4}$ into $\mathrm{CO}_{2}$ is also important ${ }^{8,11-16)}$.

Based on conditions described, the purposes of this study are as follows:

1) To utilize plants in order to reduce the cost and simplify the maintenance as a low-cost treatment system; 
2) In order to optimize the removal method for greenhouse gases and nutrients, it is expected that a quantitative evaluation of the correlation between purifying functions and volumes of emitted greenhouse gases will be obtained;

3) A method to remove nutrients and to suppress $\mathrm{CH}_{4}$ and $\mathrm{N}_{2} \mathrm{O}$ generation at the same time with ecoengineering should be developed;

4) Purifying functions and characteristics of greenhouse gas emission should be clarified for the nutrient removal system, which is a hybrid process combining soil treatment and purification by aquatic plants, as an ecoengineering method.

\section{MATERIALS AND METHODS}

The main purpose of this study is to find a method to remove nitrogen and phosphorous as limiting factors of eutrophication, and to suppress the generation of $\mathrm{CH}_{4}$ and $\mathrm{N}_{2} \mathrm{O}$ as greenhouse gases in the units in which Phragmites australis and Zizania latifolia are planted as a soil treatment system with aquatic plants. The result was analyzed to connect the reactions of plants and the rhizosphere shown in Figure 1 to actions for eutrophication and greenhouse gases.
Equipments for experiment Vegetation pots used for this study were placed in outdoor location. Since environmental factors such as water temperature and radiation vary with the seasons under natural environments in outdoor locations, the purifying function, bacterial activity and characteristics of plant growth were analyzed accordingly.

The purifying system, which utilized sediment with aquatic plants, used polypropylene cylindrical containers (pots) with a diameter of $50 \mathrm{~cm}$ and a height of $100 \mathrm{~cm}$, and which contain river sand with a depth of $60 \mathrm{~cm}$ (Figure 2). In each pot, Phragmites australis or Zizania latifolia were planted, and the water level was adjusted to a depth of $30 \mathrm{~cm}$ over the sand surface. Water flows into the top of the pots, runs through the pots and the sand layer, and flows out. The generated gases were collected as needed. For collecting gases, the top of the pot was covered by a cylindrical gas compartment ${ }^{8)}$ (capacity of $480 l$ ), and the gases in the compartment were collected into a gaspack using a pump. The flowchart of the purifying system utilizing sediment with vegetation employed in this study is shown in Figure 3.

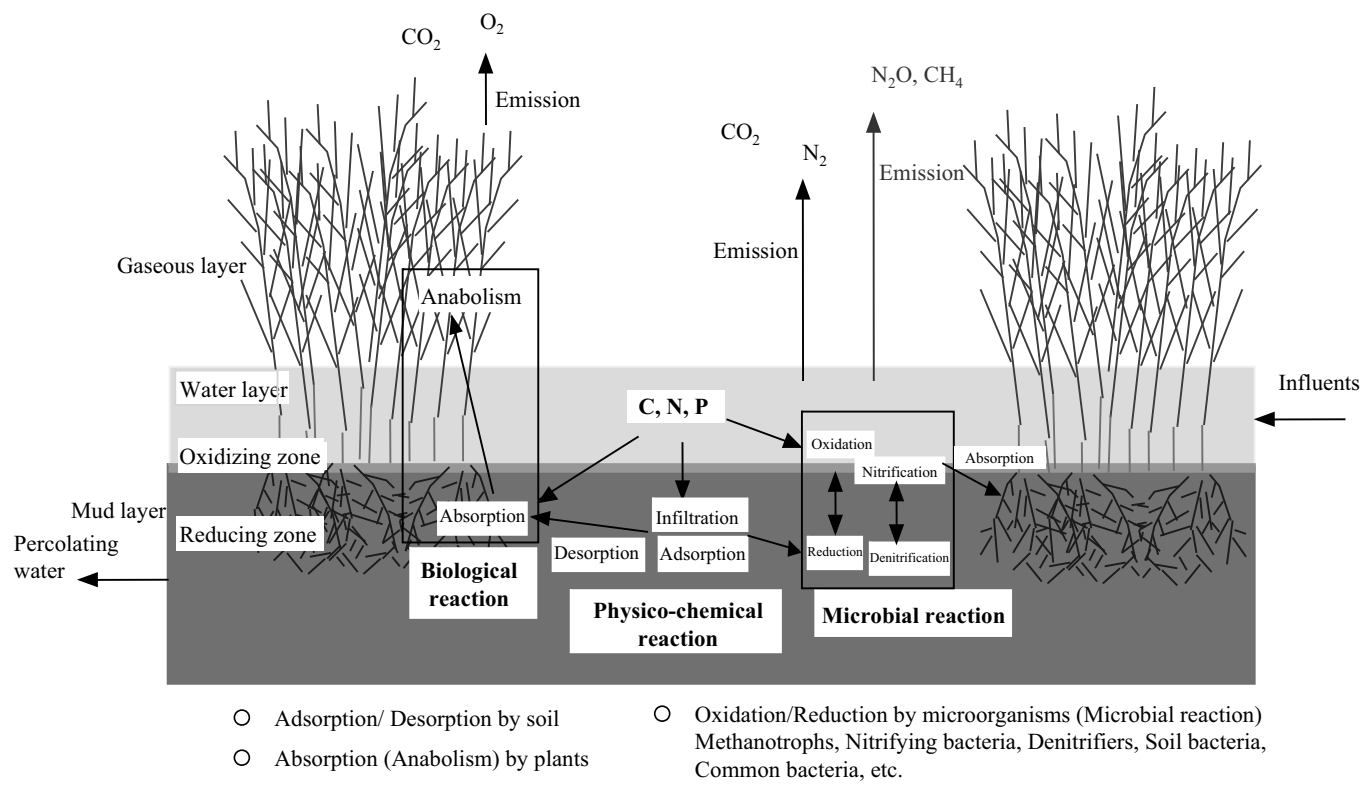

Fig. 1 Flow chart of reactions in plants and rhizosphere 


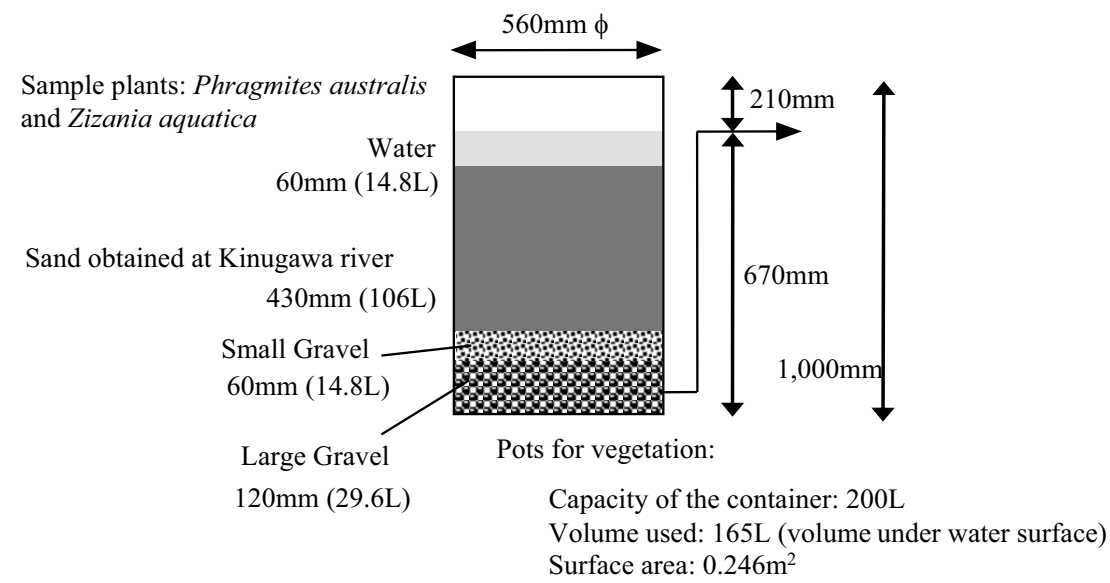

Fig. 2 Profile of the experimental pot used before vegetation

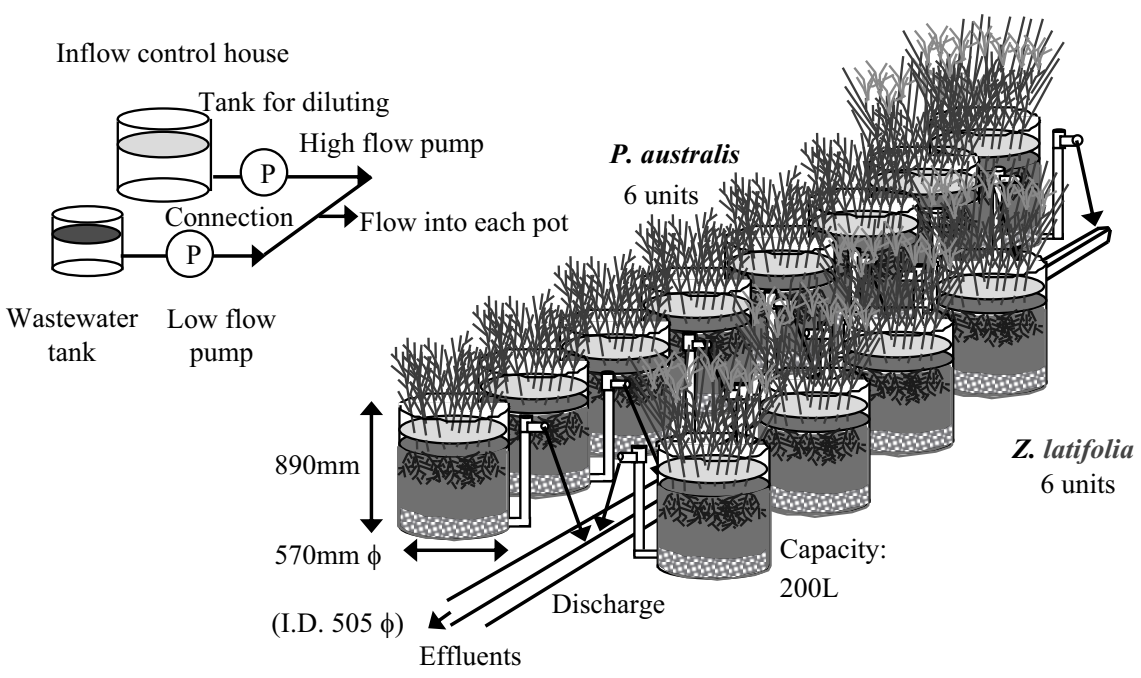

Fig. 3 Experimental unit for water purification utilizing aquatic plants

Sample plants The plants utilized in this study were Phragmites australis and Zizania latifolia, which are distributed in Japan and other Asian areas. P. australis and $Z$. latifolia have very different characteristics in their rootstalks: the root of $P$. australis has many thin roots whereas the root of $Z$. latifolia has many thicker roots ${ }^{8)}$. The plants for this study were collected from the lakeside at Lake Kasumigaura in Ibaraki Prefecture, $60 \mathrm{~km}$ Northeast of Tokyo, Japan.

Wastewater used in this study The filled sand was obtained in rivers flowing into Lake Kasumigaura in order to make analysis quantitatively. Artificial wastewater containing meat extract and dextrin etc. was used to understand the reaction mechanism adequately. Table 1 shows the composition of the artificial wastewater.

Experiment conditions Since actual household effluents are diluted in a natural water area, and discharged directly to the public water bodies in the developing countries, the purifying capability in different 
concentrations of wastewater was evaluated in this experiment. The influent loads were adjusted into three conditions based on standard loads of household wastewater: water volume of $200 l \cdot$ person $^{-1} \cdot$ day $^{-1}$, BOD 40, COD 20, $\mathrm{T}-\mathrm{N} 10$, and $\mathrm{T}-\mathrm{P} 1 \mathrm{~g} \cdot$ person $^{-1}$. day $^{-1}$. The three conditions are BOD $200 \mathrm{mg}$. $l^{-1}\left(\mathrm{COD} 100, \mathrm{~T}-\mathrm{N} 50\right.$, and $\left.\mathrm{T}-\mathrm{P} \quad 5 \mathrm{mg} \cdot l^{-1}\right)$, $100 \mathrm{mg} \cdot l^{-1} \quad(\mathrm{COD} 50, \mathrm{~T}-\mathrm{N}$ 25, and $\mathrm{T}-\mathrm{P}$ $\left.2.5 \mathrm{mg} \cdot l^{-1}\right)$, and $50 \mathrm{mg} \cdot l^{-1}(\mathrm{COD} 25, \mathrm{~T}-\mathrm{N} 12.5$, and $\left.\mathrm{T}-\mathrm{P} 1.25 \mathrm{mg} \cdot l^{-1}\right)$. The hydraulic residence time was adjusted to a period of seven days ${ }^{17)}$. The experiment conditions are shown in Table 2.

Analysis items and methods The effluents after infiltration through the pots were utilized as samples for analysis of nitrogen, phosphorus, and organic substances. As organic substances, TOC and DOC were measured $^{18)}$. In order to measure DOC, the sample was filtrated with a glass filter (Whatman GC/F). When TOC and DOC were measured, one to two drops of concentrated hydrochloric acid was added into the sample, and the sample was analyzed with TOC-5000A (Shimadzu Corporation).

Table 1 Composition of artificial wastewater

\begin{tabular}{|c|c|}
\hline & $\left(\mathrm{BOD} 200 \mathrm{mg} \cdot l^{-1}\right)$ \\
\hline Dextrin & $30.6 \mathrm{mg}$ \\
\hline Bacto peptone & $65.4 \mathrm{mg}$ \\
\hline Yeast extract & $65.4 \mathrm{mg}$ \\
\hline Meat extract & $74.6 \mathrm{mg}$ \\
\hline Urea $\left(\mathrm{NH}_{2}\right)_{2} \cdot \mathrm{CO}$ & $48.9 \mathrm{mg}$ \\
\hline $\mathrm{NaCl}$ & $6.6 \mathrm{mg}$ \\
\hline $\mathrm{MgSO}_{4} \cdot 7 \mathrm{H}_{2} \mathrm{O}$ & $4.0 \mathrm{mg}$ \\
\hline $\mathrm{KH}_{2} \mathrm{PO}_{4}$ & $18.6 \mathrm{mg}$ \\
\hline $\mathrm{KCl}$ & $13.4 \mathrm{mg}$ \\
\hline
\end{tabular}

Table 2 Outline of experimental conditions

\begin{tabular}{c|c|c|c|c}
\hline $\begin{array}{c}\text { Run } \\
\text { No }\end{array}$ & $\begin{array}{c}\text { Influent } \\
\begin{array}{c}\mathrm{BOD} \\
\left(\mathrm{mg} \cdot l^{-1}\right)\end{array}\end{array}$ & $\begin{array}{c}\text { Influent } \\
\left.\mathrm{T}-\mathrm{N} \cdot l^{-1}\right)\end{array}$ & $\begin{array}{c}\text { Influent } \\
\mathrm{T}-\mathrm{P} \cdot \\
\left(\mathrm{mg} \cdot l^{-1}\right)\end{array}$ & $\begin{array}{c}\text { HRT } \\
(\text { Days })\end{array}$ \\
\hline 1 & 50 & 12.5 & 1.25 & 7 \\
2 & 100 & 25 & 2.5 & 7 \\
3 & 200 & 50 & 5 & 7 \\
\hline
\end{tabular}

Note: Air temperature change from 0 to $37^{\circ} \mathrm{C}$ and water temperature change from 0 to $32^{\circ} \mathrm{C}$ in the experimental period.
BOD was analyzed in accordance with the Sewage Water Testing Methods: a diluted sample was put into an incubation bottle, oxygen consumption immediately before the experiment and on the fifth day of the experiment were analyzed by the electrode method for dissolved oxygen ${ }^{18)}$. Nitrogen and phosphorus were analyzed with the TRRACS2000 (Shimadzu Corporation) ${ }^{18)}$. The analysis items were total nitrogen $(\mathrm{T}-\mathrm{N})$, total phosphorus $(\mathrm{T}-\mathrm{P})$, ammonia nitrogen $\left(\mathrm{NH}_{4}-\mathrm{N}\right)$, nitrate nitrogen $\left(\mathrm{NO}_{3}-\mathrm{N}\right)$, nitrite nitrogen $\left(\mathrm{NO}_{2}-\mathrm{N}\right)$, and phosphate-phosphorus $\left(\mathrm{PO}_{4}-\mathrm{P}\right)$. The samples for $\mathrm{T}-\mathrm{N}, \mathrm{T}-\mathrm{P}, \mathrm{NH}_{4}-\mathrm{N}$, $\mathrm{NO}_{3}-\mathrm{N}, \mathrm{NO}_{2}-\mathrm{N}$, and $\mathrm{PO}_{4}-\mathrm{P}$ were treated with the following process before the measurement: the sample, filtrated with a glass filter (Whatman GC/F), and a solution used as an agent for degradation in which $4 \mathrm{~g}$ of potassium peroxydisulfate and $0.9 \mathrm{~g}$ of sodium hydroxide were dissolved into $100 \mathrm{ml}$ of water, were mixed at the ratio of 2 to 1 ; and the mixture was heated in an autoclave at $121{ }^{\circ} \mathrm{C}$ for 70 minutes in the case of $\mathrm{T}-\mathrm{N}$, $\mathrm{T}-\mathrm{P}$.

$\mathrm{CH}_{4}$ and $\mathrm{N}_{2} \mathrm{O}$ as greenhouse gases were analyzed by gas chromatography after collection through the cylindrical gas compartment on the pot to a Tedlar bag by pump $^{3)}$. In order to improve the accuracy of measurement, the greenhouse gas expected to exceed the suitable range for analysis was diluted by argon gas before the measurement. The samples were obtained over time, with a total of four samples taken at intervals of one hour. It took about 8 minutes to analyze methane and 7 minutes to analyze nitrous oxide. The generated amount of green house gas was analyzed and evaluated based on the peak obtained. The method of gas sampling is shown in Figure 4.

\section{RESULTS AND DISCUSSION}

Growth characteristics of the aquatic plants This experiment on the growth characteristics of Phragmites australis and Zizania latifolia started in the summer. Although the $P$. australis and $Z$. latifolia planted in the summer grew until late October, the growth of P. australis- BOD 200 $\mathrm{mg} \cdot l^{-1}$ units was the slowest. It is suspected that the high level of pollution loads in the 


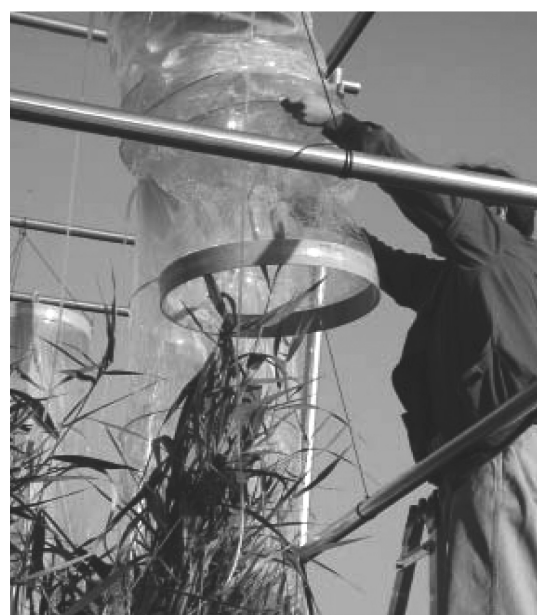

Setting of cylindrical gas compartment

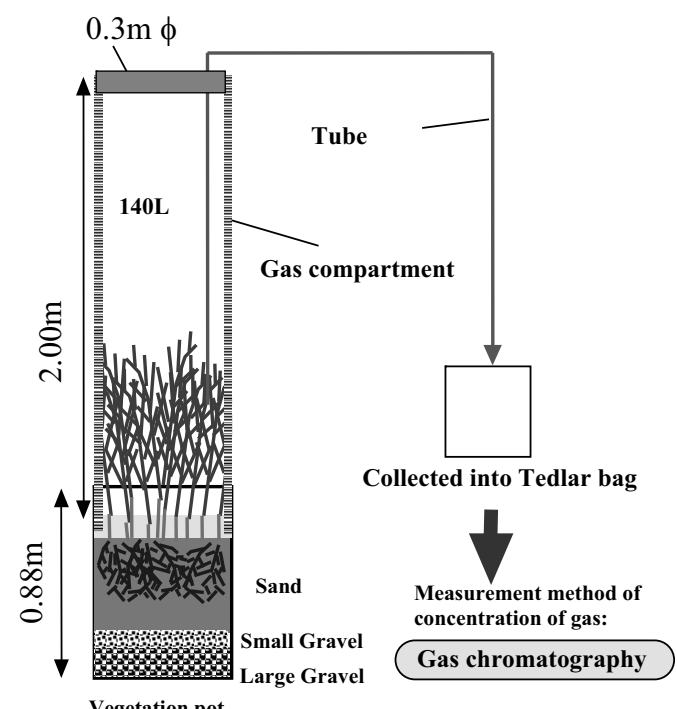

Vegetation pot

Fig. 4 Schematic diagram of sampling method for greenhouse gases

units from the beginning of vegetation decayed the rootstalks and suppressed the growth significantly. Since all the $Z$. latifolia units showed high rates of growth, $Z$. latifolia was considered to be tolerant of high levels of pollution loads. The leaves and stems started dying rapidly from late October in all the units. This is because the temperature and radiation dropped at the onset of winter. However, the rootstalks of $P$. australis and $Z$. latifolia survived in the sand layer. Particularly, the rootstalks of $Z$. latifolia had even some shoots. Hence, it is suggested that the rhizosphere is important with regards to the characteristics of $P$. australis and $Z$. latifolia, and has purifying functions during the winter.

\section{Organic substance removal capabili- ties The organic substance removal} capabilities of the purifying systems utilizing sediment with vegetation are shown in Figures 5 and 6 . With regard to these capabilities, the BOD removal rate was $90 \%$ or more in Phragmites australis units in all the pollution loads. BOD removal rate in the treated water was stable from summer through to even winter, when both leaves and stems died back. Zizania latifolia also showed a BOD removal rate of $90 \%$ or more during the experiment. However, the absolute level of BOD concentration in treated water was around $5 \mathrm{mg} \cdot l^{-1}$ in $P$. australisBOD $200 \mathrm{mg} \cdot l^{-1}$ units from summer to autumn, while it increased to about $15 \mathrm{mg} \cdot l^{-1}$ in winter. Similarly, in Z. latifolia-BOD 200 $\mathrm{mg} \cdot l^{-1} \quad$ units, the removal capabilities decreased to about $15 \mathrm{mg} \cdot l^{-1}$ in winter. Nevertheless, the removal capabilities were around $2 \mathrm{mg} \cdot l^{-1}$ in most of the other units. Thus, although the load at BOD $200 \mathrm{mg} \cdot l^{-1}$ was considered to be too high for $P$. australis with respect to BOD removal, sufficient purification can be expected in other conditions.

It is considered that not only absorption by plants, but also bacteria and microorganisms in water or on rootstalks, and soil microorganisms in rhizosphere contribute significantly to removal of organic substances. In soil treatment using aquatic plant systems, the biomass in water plays an important role. In order to increase the removal capabilities in the winter, reducing the pollution load is a realistic solution because it is difficult to control the temperature. Therefore, it is necessary to prolong hydraulic residence time to stabilize the treatment capabilities.

Since COD includes persistent substances, 
a method with high COD removal capabilities is effective and efficient for water treatment; therefore COD removal capabilities were evaluated. In this experiment, COD removal capability in $Z$. latifolia- BOD $50 \mathrm{mg} \cdot l^{-1}$ units was $70 \%$ in summer and autumn, and $80 \%$ in winter even though the concentration of influents was higher. In $Z$. latifolia- BOD $100 \mathrm{mg} \cdot l^{-1}$ units, it was $75 \%$ in summer and autumn, and $80 \%$ or more in winter. In $Z$. latifolia- BOD $200 \mathrm{mg} \cdot l^{-1}$ units, it was $70 \%$ in summer and autumn, and $85 \%$ or more in winter. Accordingly, Z. latifolia had a high COD removal rate throughout the period of summer, autumn, and winter, even after the plants died. Since $P$. australis units showed similar values, removal of COD using plants

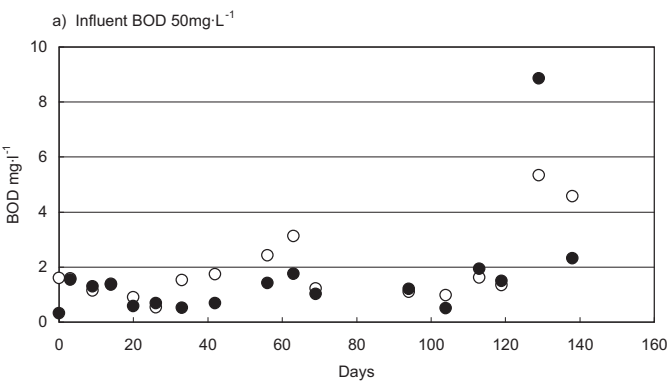

b) Influent BOD $100 \mathrm{mg}^{-1}$

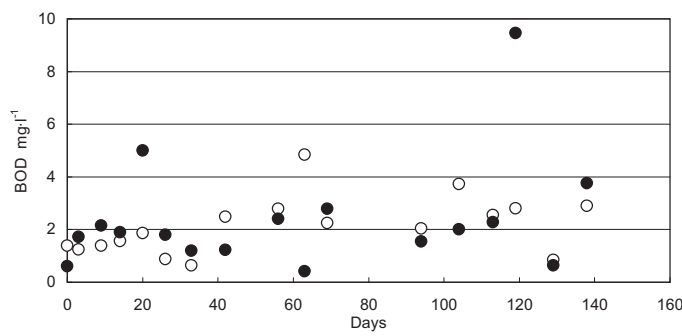

c) Influent BOD $200 \mathrm{mg} \cdot \mathrm{l}^{-1}$

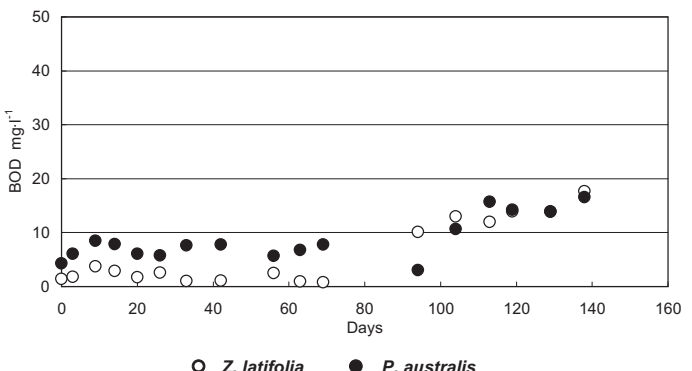

Fig. 5 Change in BOD of treated water with time is very effective.

Ability to remove nutrients With regard to the purifying systems utilizing sediment with vegetation, the forms of nitrogen and their removal capabilities are shown in Figures 7 and 8. The forms of phosphorous substances and their removal capabilities are shown in Figures 9 and 10. Abilities of $P$. australis and $Z$. latifolia to remove nutrients were high in the summer, and decreased from late October because the plants died due to the decreasing temperature. That is, with respect to nitrogen removal, influents include only about $10 \%$ of ammonia, and effluent ammonia of $P$. australis-BOD 200 $\mathrm{mg} \cdot l^{-1}$ exceed the level in influents in some

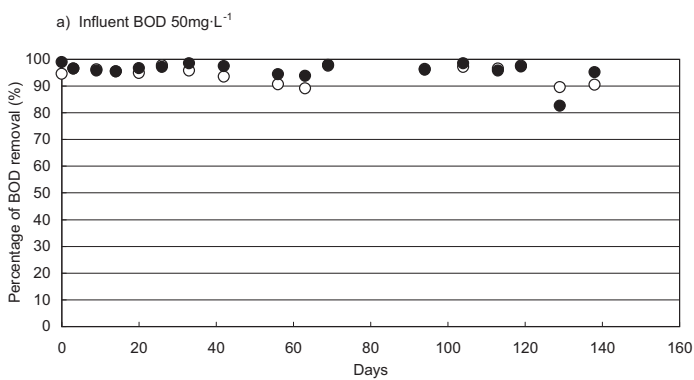

b) Influent BOD $100 \mathrm{mg} \cdot \mathrm{L}^{-1}$

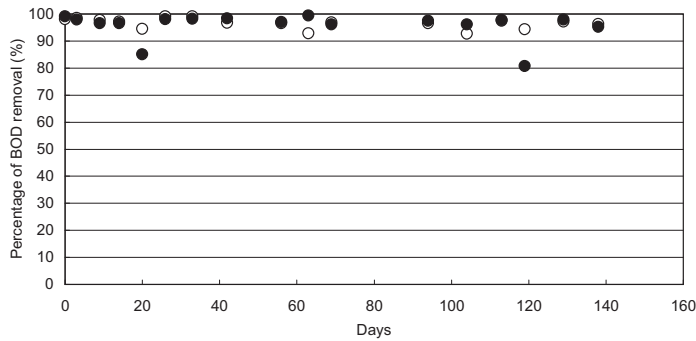

c) Influent BOD $200 \mathrm{mg} \cdot \mathrm{I}^{-1}$

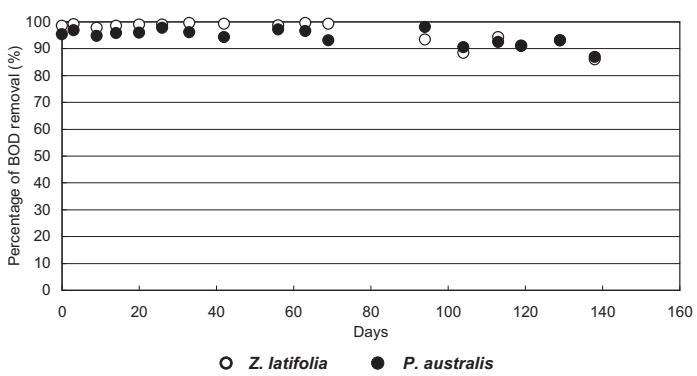

Fig. 6 Change in percentage of BOD removal with time 
units. This indicates that deamination occurs while nitrification does not work in this condition. When the temperature is low, the units with high pollution loads showed low purifying capabilities, while there were not significant differences in the units with low pollution loads. These facts are shown in the correlation of influent loads and water temperature in Figures 11 and 12. Needless to say, the fact that plants die due to low temperature and purifying capabilities gradually decrease in units with high pollution loads means that the activities of plants and bacteria decrease. Consequently, residence time should be prolonged in cold periods, when some units are frozen. Although all the units showed stable

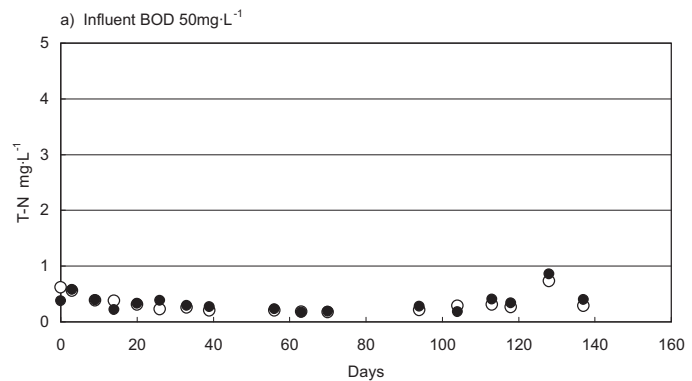

b) Influent BOD $100 \mathrm{mg} \cdot \mathrm{L}^{-1}$

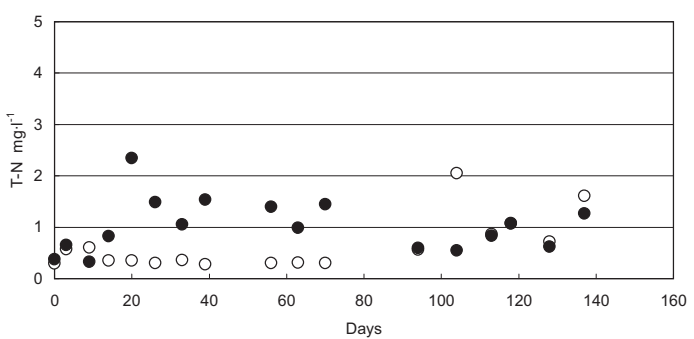

c) Influent BOD $200 \mathrm{mg} \cdot \mathrm{l}^{-1}$

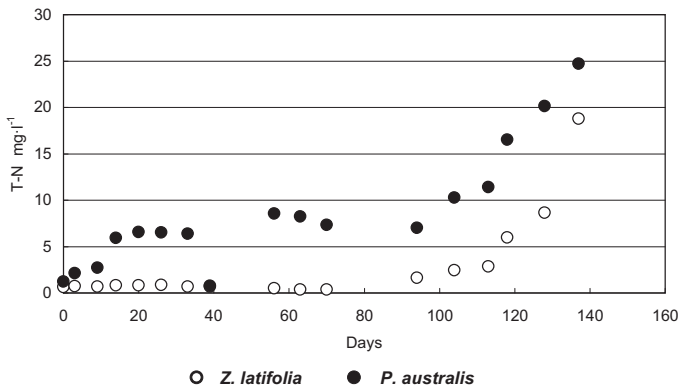

Fig. 7 Change in $\mathrm{T}-\mathrm{N}$ of treated water with time phosphorus removal capabilities in the beginning, the concentration of phosphorus in treated water increased in some units after certain period as shown in the figure. This means that the absorption of phosphorus by plants and adsorption to soil were saturated. Z. latifolia units maintained high removal capabilities of nitrogen and phosphorus compared to $P$. australis; a difference that may be due to the growth of roots. This implies that purifying capabilities vary depending on strains of aquatic plants.

The results of this experiment showed that in the growing period, sustainable levels of nitrogen and phosphorus were 0.5 and 0.08 $\mathrm{mg} \cdot l^{-1}$ in $P$. australis- BOD $50 \mathrm{mg} \cdot l^{-1}$ units, 0.5 and $0.13 \mathrm{mg} \cdot l^{-1}$ in $P$. australis- BOD 100
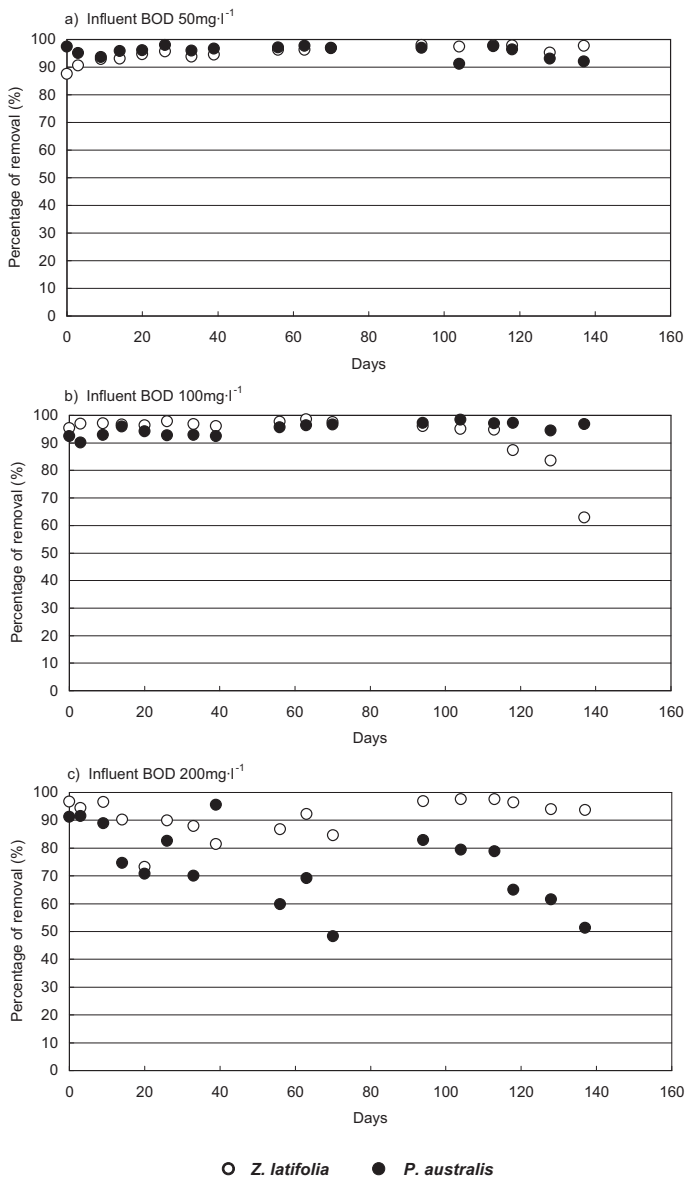

Fig. 8 Change in percentage of $\mathrm{T}-\mathrm{N}$ removal with time 
$\mathrm{mg} \cdot l^{-1}$ units, and 8.0 and $2.0 \mathrm{mg} \cdot l^{-1}$ in $P$. australis-BOD $200 \mathrm{mg} \cdot l^{-1}$ units, respectively. They were 0.2 and $0.08 \mathrm{mg} \cdot l^{-1}$ in $Z$. latifoliaBOD $50 \mathrm{mg} \cdot l^{-1}$ units, 0.5 and $0.09 \mathrm{mg} \cdot l^{-1}$ in Z. latifolia-BOD $100 \mathrm{mg} \cdot l^{-1}$ units, and 1 and $0.1 \mathrm{mg} \cdot l^{-1}$ in $Z$. latifolia-BOD $200 \mathrm{mg} \cdot l^{-1}$ units, respectively, in the low loading, particularly, aquatic plant. Soil purification system have high performance of nitrogen and phosphorus removal, therefore, reductions of algal growth potential can be expected ${ }^{19)}$. Further evaluation is needed from the long term perspective. In addition, the removal capabilities significantly decreased in the winter.

The characteristics of greenhouse gas

a) Influent BOD $\left.50 \mathrm{mg} \cdot\right|^{-1}$

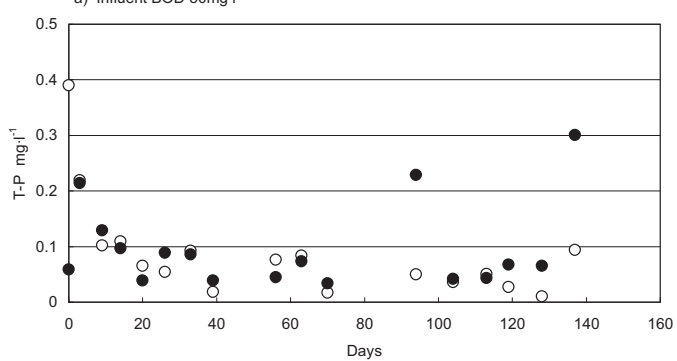

b) Influent BOD $100 \mathrm{mg} \cdot \mathrm{l}^{-1}$

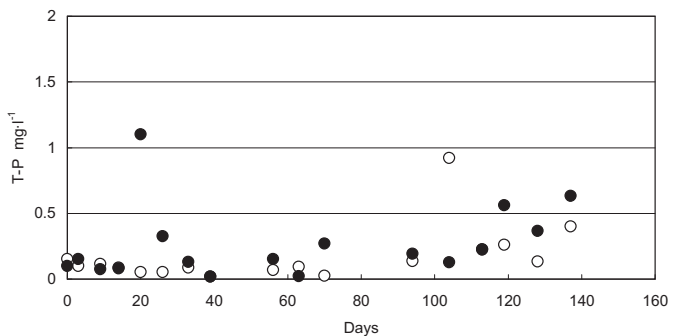

c) Influent BOD $200 \mathrm{mg} \cdot \mathrm{I}^{-1}$

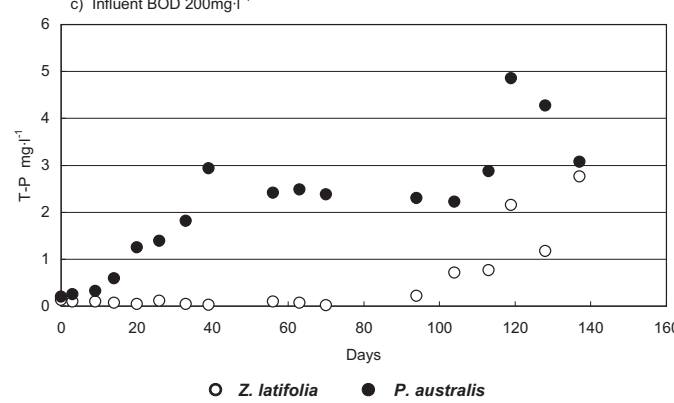

Fig. 9 Change in T-P of treated water with time emission Gas generation when Phragmites australis and Zizania latifolia fully grew was analyzed. All the units in which $P$. australis and $Z$. latifolia were planted showed little $\mathrm{N}_{2} \mathrm{O}$ generation. Dass reported the similar results ${ }^{13)}$. On the other hand, $\mathrm{CH}_{4}$ generation varied depending on the loading conditions, and the amount of the gas emitted significantly increased under high pollution loads. Generation rates of $\mathrm{CH}_{4}$ per unit area were calculated based on the change of $\mathrm{CH}_{4}$ concentration during the summer time (average in August, September) in the gas compartment. They were $62.8,82.3$, and $224.0 \mathrm{mg} \cdot \mathrm{m}^{-2} \cdot \mathrm{h}^{-1}$ in $Z$. latifolia-BOD 50, 100 , and $200 \mathrm{mg} \cdot l^{-1}$ units, respectively; and 11.2 , 16.5 , and $126.8 \mathrm{mg} \cdot \mathrm{m}^{-2} \cdot \mathrm{h}^{-1}$ in $P$. australis-
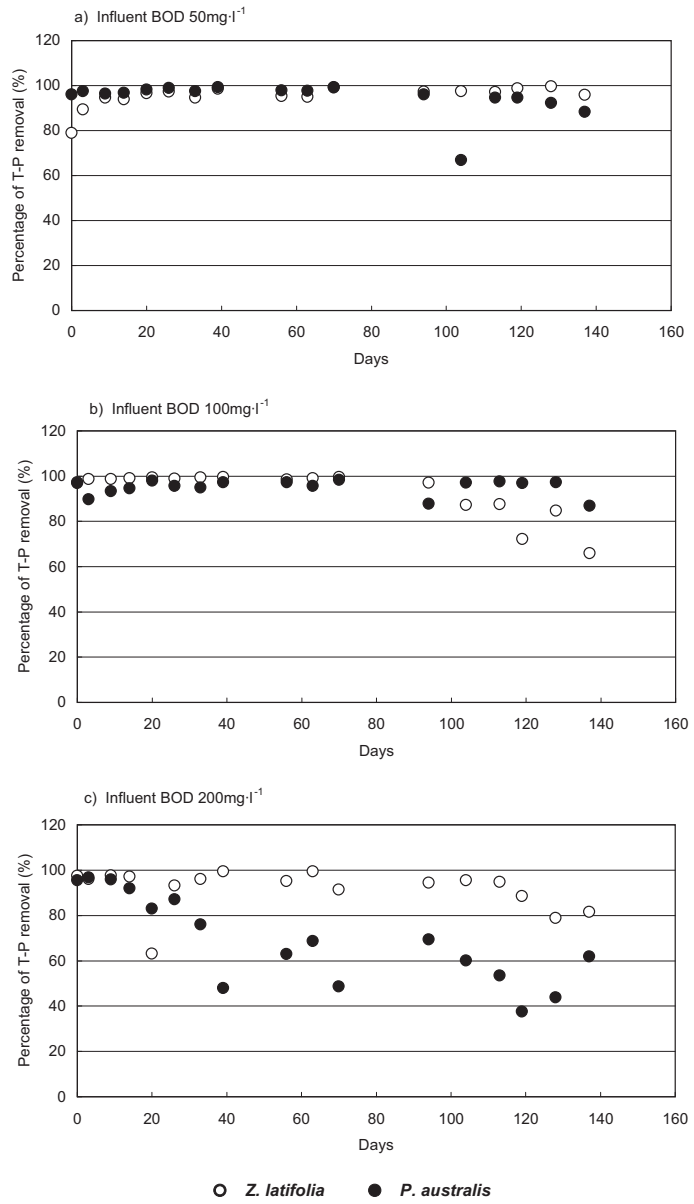

Fig. 10 Change in percentage of T-P removal with time 
BOD 50, 100, and $200 \mathrm{mg} \cdot l^{-1}$ units; respectively. As shown in Figures 13 and 14, the generation rate of $\mathrm{CH}_{4}$ is much higher in $Z$. latifolia units than in $P$. australis units. It is suspected that the differences between the plants were caused by the structures of the roots zone areas. Compared to $Z$. latifolia, $P$. australis has thinner roots that grow compactly. It is suggested that when free oxygen absorbed from leaves is provided to the roots, the whole rhizosphere turns aerobic and the activity of methanogens decreases while the activity of methanotrophs increases. These phenomena were observed in the Landfill site and rice field ${ }^{11,14)}$. Therefore, transport of oxygen to soil from atmosphere means important factor for making high activity of methanotrops. And
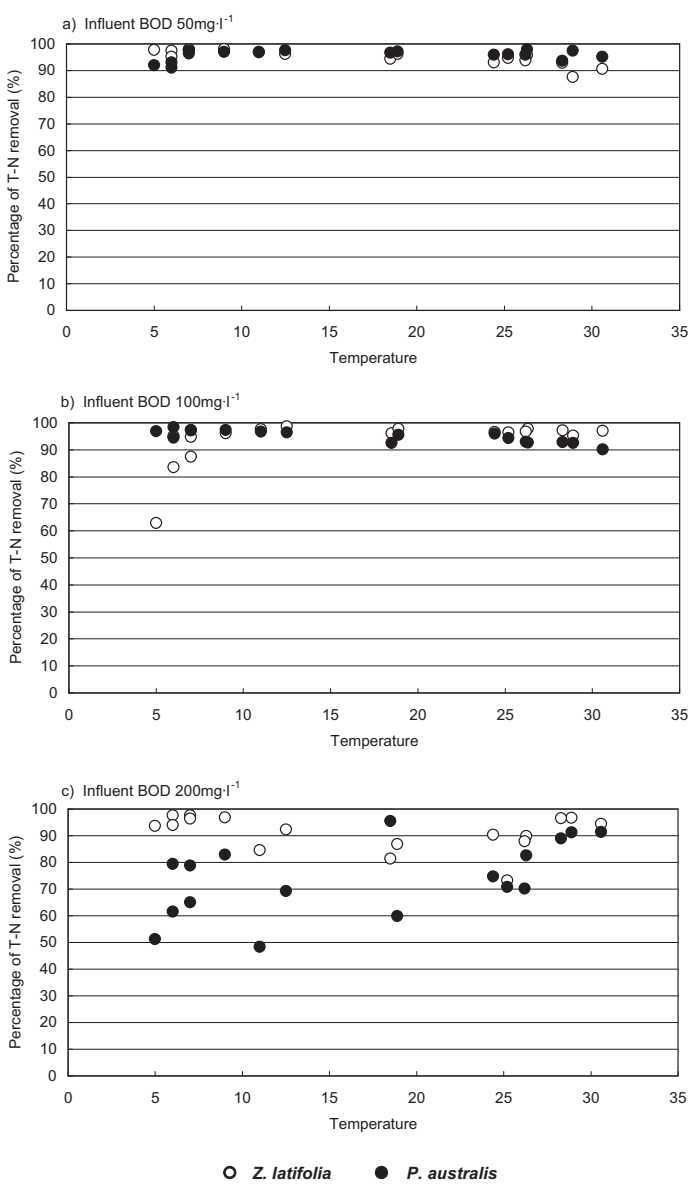

Fig. 11 Correlation between percentage of $\mathrm{T}-\mathrm{N}$ removal and water temperature then, in the aquatic plant soil purification systems, another possibility is that compared to $P$. australis units, $Z$. latifolia units had lower biomass of methanotrophs, which convert $\mathrm{CH}_{4}$ to $\mathrm{CO}_{2}$. As it was observed many thin roots exist in $P$. australis unit and many thick roots exist in $Z$. latifolia, these root zone structure may affect the different oxygen transport potential and biomass $\mathrm{CH}_{4}$ oxidizing bacteria $^{20)}$. Furthermore, under the conditions of SF (Submerged water flow) and FWS (Free water surface flow) systems, which shows different water level, SF system has less $\mathrm{CH}_{4}$ emission potential and water purification than FWS system ${ }^{21)}$. However, further analysis is needed to clarify this possibility.
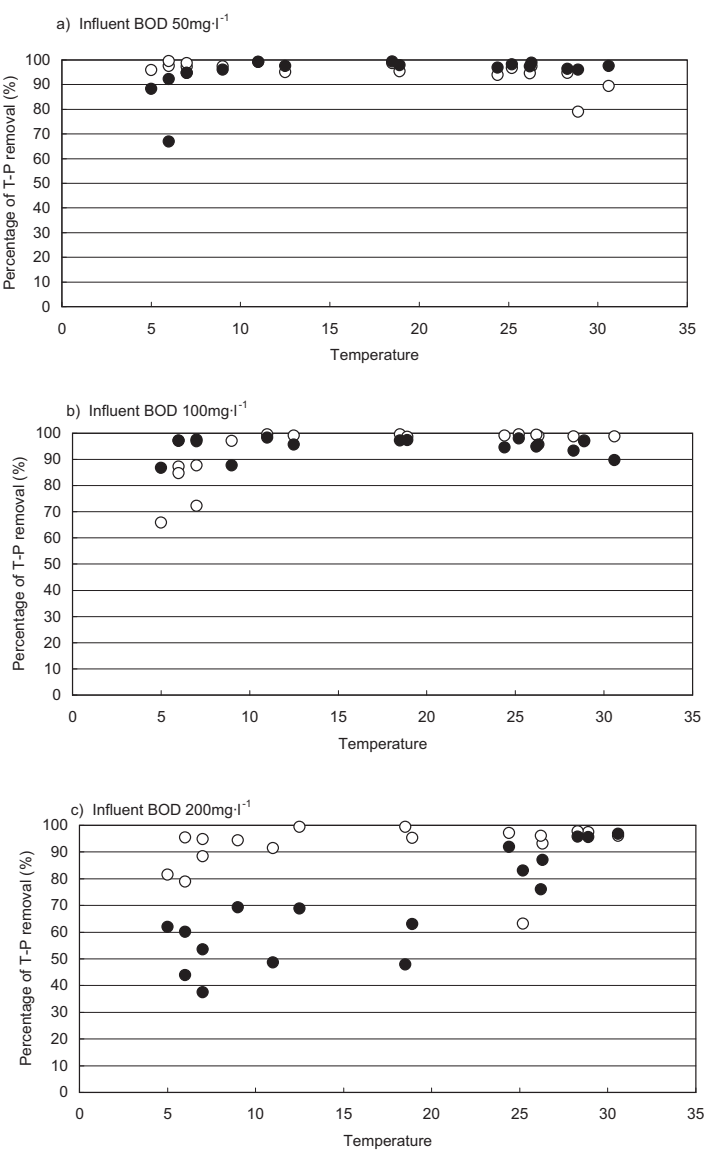

○ Z. latifolia - P. australis

Fig. 12 Correlation between percentage of T-P removal and water temperature 


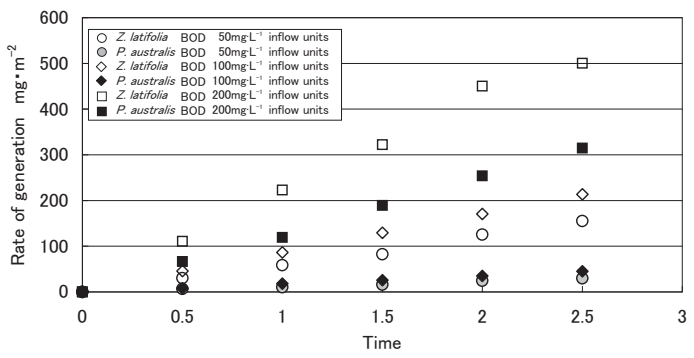

Fig. 13 Change in amount of $\mathrm{CH}_{4}$ generated with time

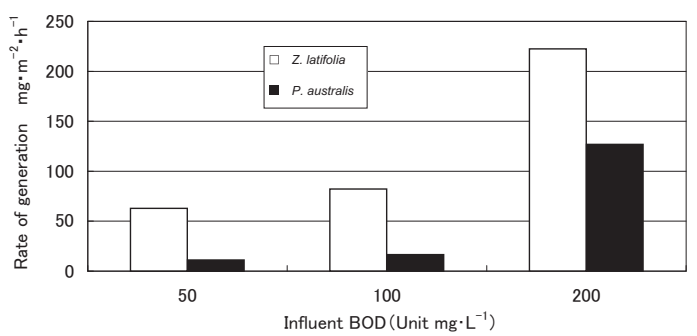

Fig. 14 Correlation between rate of $\mathrm{CH}_{4}$ generation and influent BOD

\section{CONCLUSIONS}

Characteristic analysis of the organic substance and nutrient removal and the green house gas emission in the soil treatment systems with aquatic plants was evaluated in this study. The main results obtained can be summarized as follows:

1) Although both $P$. australis and Z latifolia showed BOD removal rates of $90 \%$ or more under the conditions of HRT 7 days and influent BOD 50 200mg $\cdot l^{-1}$, the load of BOD $200 \mathrm{mg} \cdot l^{-1}$ was too high for $P$. australis in the beginning of vegetation.

2) Both P. australis and Z. latifolia showed relatively stable nitrogen removal capability from summer to autumn, but its performance slightly decreased about 30\% in winter due to the low temperature such as $7^{\circ} \mathrm{C}$.

3) The generation rate of $\mathrm{CH}_{4}$ during the summer time in $Z$. latifolia units was higher in all the loading levels of BOD 50, 100 , and $200 \mathrm{mg} \cdot l^{-1}(62.8,82.3$ and 224.0 $\mathrm{mgCH}_{4} \cdot \mathrm{m}^{-2} \cdot \mathrm{h}^{-1}$ respectively), than in those in $P$. australis units $(11.2,16.5$ and $\left.126.8 \mathrm{mgCH}_{4} \cdot \mathrm{m}^{-2} \cdot \mathrm{h}^{-1}\right)$. The reason on the observation of higher $\mathrm{CH}_{4}$ emission in $Z$. latifolia is suggested that biomass of methanotrophs is large under $P$. australis due to oxygen transport potential is higher in the $P$. australis than in the $Z$. latifolia.

4) Soil treatment systems using aquatic plants keep high purifying and $\mathrm{CH}_{4}$ emission control capabilities in low pollution loads such as BOD $50 \mathrm{mg} \cdot l^{-1}$ when water temperature is low.

Thus, aquatic plants have capabilities to suppress the generation of nutrients, organic substances, and greenhouse gases. Hence, further research on low cost and highly effective ecoengineering systems utilizing plants is expected. In order to apply ecoengineering methods based on this research result, it is required to solve the following problems.

The water purifying method with plants utilizing ecoengineering can be applied in various pollution loading conditions or characteristics of water areas by combining several systems regardless low facility building and maintenance costs. Not only nitrogen and phosphorus, but also dissolved organic substances and suspended solids can be removed. Further development of the technology to find optimum conditions to improve treatment capabilities is expected. In developing countries, water pollution worsens because of untreated drainage of household and industrial effluents, and assuring safe water sources is very difficult. Particularly, in Asian countries, immediate measures are crucial from the public health perspective. Since ecoengineering systems are inexpensive and effective, rapid development of the technologies and its proper distribution are required in developing countries,.

This research leads to the result that the treatment capability of aquatic plants itself has great potential. As the next step, the purifying capabilities and optimum conditions of the attachment of microorganisms and bacteria to rootstalks should be researched. 


\section{REFERENCES}

1 ) Yuhei INAMORI, Ryuhei INAMORI, and KONG Hai Nan: Necessity of Global Warming Protection Countermeasures and COP7 in food Industry, Journal of Food Factory, 60, 24-25, 2002

2 ) Yuhei INAMOI, and Ryuhei INAMORI: Advanced Water Treatment Using BioEco Engineering ENBIO, (1), 31-39, 2001

3 ) Y. Inamori, Y. Komochi, R. Inamori, P. Gui, H. N. Kong, and M. Mizuochi: Control of Anthropogenic $\mathrm{CH}_{4}$ and $\mathrm{N}_{2} \mathrm{O}$ Emissions From Several Industrial Sources and from Daily Human Life: Journal of Chemical Engineering of Japan, 36(4), 449-457, 2003

4 ) Y. Inamori, M. Mizuochi, N. iwami, and R. Inamori: Development of lake Water quality using bio-eco engineering system, Res. Adv. in Water Res., 2, 27-36, 2002

5 ) Sudo R.: Environment Restration using Ecoengineering, KODANSHA Scientific, Tokyo, Japan, 2002

6 ) Nicholas D. S.: Removal of nutrients from treated municipal wastewater by wetland vegetation, J.WPCF, 55, 485-491, 1983

7 ) Danuta L. and Andrew D.: Tertiary Wastewater Treatment through constructed wetland ecosystem, Env. Protection Eng., 18 (1-2), 13-23, 1992

8 ) R. Inamori, Y. Shimizu, T. Yamamoto, G. Ping, Y. Ebie, and M. Matumura: Characteris of Aquatic plant soil Purification system on the Emission of $\mathrm{CH}_{4}, \mathrm{~N}_{2} \mathrm{O}$ and Organic Substance, N-P Removal. China / USA / Japan Joint Chemical Engineering Conference, Beijing, China (October 2005)

9 ) Boeckxp P. and O. Cleemput: Estimates of $\mathrm{N}_{2} \mathrm{O}$ and $\mathrm{CH}_{4}$ Fluxes from Agricultural Lands in Various Regions in Europe, Nutr. Cycl. Agroecosyst, 60, 35-47, 2001

10) Gui Ping: Study on the Operation and Management Techniques to Control $\mathrm{CH}_{4}$ and $\mathrm{N}_{2} \mathrm{O}$ for the Constructed Wetland System, Yearly Report of the Global Environment Research of Japan in 2000, Japan Environment Agency, Tokyo, Japan, 2000

11) Jia Z., Z. Cai, H. Xu, and $X$ Li: Effect of Rice Plants on $\mathrm{CH}_{4}$ Production, Transport,
Oxidation and Emission in Rice Paddy Soil, Plant Soil., 230, 211-221, 2001

12) Chan A.S.K. and T. B. Parkin: Methane Oxidation and Production Activity in Soils from Natural and Agricultural Ecosystems, J. Environ Qual. 30, 1896-1903, 2001

13) Dass P.: Study on the Operations and Management Techniques to Control $\mathrm{CH}_{4}$ and $\mathrm{N}_{2} \mathrm{O}$ for the Natural Wastewater Treatment Process Using Soil and Vegetation, Yearly Report of the Global Environment Research of Japan in 2000, Japan Environment Agency, Tokyo, Japan (2000)

14) Humer M. and P. Lechner: Microbial Methane Oxidation for the Reduction of Landfill Gas Emissions. Proceeding of the International Conference on Solid Waste Technology and Management, $15^{\text {th }}$ RP133140 Philadelphia, USA, 1999

15) H. U. Neve, R. Wassmann, and R. S. Lantin: Factors affeiting methave emissions from rice field, Atmospheric Environment, 30 (10/11), 1751-1754, 1996

16) Kong H., Kimochi Y., Mizuochi M., Inamori R., and Inamori Y.: Study of the characteristics of $\mathrm{CH}_{4}, \quad \mathrm{~N}_{2} \mathrm{O}$ emission and methods of controlling their emission the soil trench wastewater treatment process, The Science of the Total Environment, 290, 59-67, 2002

17) Sherwood C. Reed, Ronald W. Crites, and E. Joe Middlebrooks: Natural Systems for Waste Management and Treatment, Second Edition, McGraw-Hill, Inc., 1995

18) Japan Sewage Works Association: Sewage Water Testing Method, Tokyo, Japan, 1994

19) R. Inamori, P. Gui, Y. Shimizu, K. Xu, K. Kimura, and Y. Inamori: Effect of Constructed Wetland Structures on Wastewater Treatment and Its Evaluation by Algal Growth Potential Test, Japanese Journal of Water Treatment Biology, 41, 159-170, 2005

20) P. Gui, R. Inamori., M. Mizuochi., N. Iwami, K. Fujii, K. XU, and Y. Inamori: Comparative Study on Pollutants Removals and non$\mathrm{CO}_{2}$ Greenhouse Gas Emissions Control from Two Typical Reed Planted Constructed Wetlands, 9th International Conference on the Conservation and Management of Lakes, Third Section 
Meeting, Ootu, Japan (November 2001)

21) R. Inamori, Y. Shimizu, T. Yamamoto, G. Ping, and Y. Ebie: Characteristic of Aquatic plant soil purification system on the Emission of $\mathrm{CH}_{4}, \quad \mathrm{~N}_{2} \mathrm{O}$ and Organic substance, N-P Removal, China/USA/
Japan Joint Chemical Engineering Conference, SE13B-4, Beijing, China (October 2005)

(Submitted 2006. 8. 3)

(Accepted 2006. 9. 12) 
